\title{
KEPEMIMPINAN DALAM KEBERAGAMAN INDONESIA MEMAHAMI GLOBALISASI DENGAN ANALOGI THE LEXUS AND OLIVE TREE
}

\author{
Oleh : Pdt. Dr. Fredrik U. Wowor, M.Th \\ Dosen Pasca Sarjana STT Erikson-Tritt Manokwari \\ Email : woworfredrik2664@gmail.com
}

\begin{abstract}
ABSTRAK
Penelitian ini merupakan kajian pustaka untuk mengkaji dampak globalisasi. Kebenaran fundamental mengenai globalisasi adalah bahwa globalisasi itu timbul dari bawah, dari tingkat jalanan, dari dasar jiwa setiap orang, dan dari aspirasi terdalam mereka. Globalisasi adalah produk dari demokratisasi di bidang keuangan, teknologi, dan informasi, tetapi yang mendorong ketiganya adalah keinginan dasar setiap manusia yaitu kehidupan yang lebih baik, kehidupan dengan pilihan yang lebih banyak mengenai apa yang dimakan, apa yang dipakai, dimana bertempat tinggal, kemana bepergian, bagaimana bekerja, apa yang dibaca, apa yang ditulis, dan apa yang dipelajari.
\end{abstract}

Kata Kunci : Globalisasi, The Lexus and Olive Tree; Kepemimpinan 


\section{A. PENDAHULUAN}

Indonesia, negara dengan penduduk yang berasal dari banyak suku, ras dan agama. Bhineka Tunggal Ika yang menjadi pemersatu dari Sabang sampai Merauke menjadi salah satu bukti bahwa Indonesia menghargai berbagai bentuk perbedaan tersebut. Dalam dekade terkahir wacana globalisasi terus menggelinding. Wacana ini, semakin diperkaya oleh praktik-praktik hubungan antar negara-bangsa, serta diperkaya pula oleh bagaimana sistem ekonomi dunia menggeliat menuju apa yang disebut sebagai "free trade system." Globalisasi, sebagaimana civil society, merupakan istilah yang hadir dan segera populer pasca perang dingin.

Globalisasi bukanlah merupakan gejala yang alami seperti angina topan, badai ataupun hujan. Globalisasi adalah gejala yang merupakan hasil pemikiran dan praktek dari manusia, seberapapun kompleks proses yang membentuknya. Dalam arti ruang, globalisasi mengacu pada kenyataan bahwa dunia semakin mengecil (the shrinkening world) dan merupakan suatu ruang yang tunggal (single space atau juga disebut a planetary unit) dan dengan kenyataan ini mau tidak mau memaksa para perencana strategi untuk berfikir dalam kerangka global. Dalam arti kesadaran manusia sekarang ini makin sadar bahwa setiap kejadian yang terjadi di penghujung bumi utara dapat berimplikasi terhadap belahan bumi selatan.

Thomas L. Friedman memformulasikan pemikirannya tentang globalisasi dengan membagi globalisasi ke dalam tiga tahap atau fase. Tahap pertama, globalisasi 1.0, diawali dan disimbolkan oleh Columbus tahun 1492 saat mulai melangsungkan upaya pelayaran untuk menemukan belahan bumi lainnya. Era ini mengantarkan dunia pada dunia baru, opening trade between the old world and the new world, tulis Friedman. Era ini berlangsung sampai kurun waktu tahun 1800-an, abad ke-18. Kekuatan pemicu perubahan era ini masih relatif sederhana, diilustrasikan oleh Friedman sebagai situasi yang masih bertumpu pada seberapa besarnya kekuatan muscle (otot, tenaga manusia), kekuatan kuda (horsepower), kekuatan angin (windpower), sampai akhirnya kekuatan mesin-mesin yang digerakkan oleh tenaga uap (steam prower).

Globalisasi 2.0, berlangsung kurun waktu 1800-an sampai tahun 2000. Era menyempitnya dunia dari ukuran medium (medium size) menjadi ukuran yang lebih kecil (small size), ditandai dengan 
munculnya perusahaan-perusahaan multinasional kelas dunia yang berkiprah di era pasar bebas dan ditandai dengan munculnya kekuatan tenga kerja. Era ini ditandai pertama kali oleh ekspansi perusahaanperusahaan Belanda dan Inggris dan terjadinya revolusi industri sejalan dengan ditemukannya mesin-mesin.

Globalisasi 3.0, abad ke-20 dan setelahnya, era ini semakin menyempitnya ukuran dunia dari ukuran yang kecil (small size) menjadi ukuran yang sangat kecil (tiny size). Bertumpu pada kekuatan individu untuk membangun kolaborasi dan kompetisi pada global ini. Teknologi software (perangkat lunak) menjadi pemicunya. Pertanyaan pada era ini bagaimana memberdayakan individu? "Kalau globalisasi 1.0 dan 2.0 sepertinya milik bangsa Eropa dan Amerika, maka globalisasi 3.0 milik semua orang, milik semua bangsa, semua negara, milik siapa pun tanpa mengenal diskriminasi, bukan milik Barat atau orang-orang kulit putih.

Globalisasi telah membuat dunia kecil, semakin tipis, semakin dekat, adalah juga lahirnya berbagai kesepakatan dalam aktivitas perdagangan dan ekonomi global yang didorong oleh lahirnya IMF, The G8, The World Bank, WTO dan sebagainya. Ke depan, kata Friedman, globalisasi akan semakin dahsyat.

\section{B. KAJIAN TEORITIK}

\section{Kepemimpinan}

Kepemimpinan memiliki arti tentang cara memimpin, dalam Kamus Besar Bahasa Indonesia dari akan kata "pimpin" yang berarti membimbing, dituntun. Kepemimpinan adalah terjemahan kata "leadership" yang berasal dari akar kata "leader" adalah orang yang memimpin sedangkan kepemimpinan merupakan suatu jabatan. Kepemimpinan secara umum memiliki banyak definisi, dari berbagai top leader definisi kepemimpinan selalu berdasarkan pengalaman empiris, tetapi definisi yang berbeda-beda disatukan untuk satu tujuan bersama-sama. Herwinwsastra mengutip J. Oswald Sanders dalam bukunya George Bama berjudul Leadership, kepemimpinan adalah pengaruh, kemampuan seseorang yntuk mempengaruhi orang lain 
(Herwinesastra, Pengaruh kepemimpinan Kristen di Era Globalisasi Abad 21, Kalam Hidup, Bandung 2015:2-3).

Dalam paper karangan Fredrik Wowor tentang dasar-dasar kepemimpinan dan kepemimpinan Kristen mengutip dari Hasibuan (1994) mengatakan : "Pemimpin adalah seorang yang mempergunakan wewenang dan kepemimpinannya untuk mengarahkan bawahan dalam mengerjakan pekerjaannya untuk mencapai tujuan organisasi, sedangkan kepemimpinan adalah cara seorang pemimpin mempengaruhi perilaku bawahan agar mau bekerja sama dan bekerja secara produktif untuk mencapai tujuan organisasi."

Lao Tzu memiliki definisi tersendiri tentang kepemimpinan yaitu: "Pemimpin yang baik adalah seorang yang membantu mengembangkan orang lain, sehingga akhirnya mereka tidak lagi memerlukan kepemimpinan itu," John C. Maxwell memberikan definisi Leadership is influence yang diartikan kepemimpinan adalah seni mempengaruhi orang lain agar mengikuti dan melakukan apa yang kita inginkan dengan sukarela, penekanan dalam kepemimpinan John C. Maxwell adalah orang lain bersedia mengikuti dengan sukarela.

Menurut Dr. Thomas Gordon Group Centered Leadership yaitu : "Kepemimpinan dapat dikonseptualisasikan sebagai suatu interaksi antara seorang dengan suatu kelompok, tepatnya antara seorang dengan anggota-anggota kelompok. Setiap anggota di dalam interaksi memainkan peranan masing-masing dan dengan cara-cara tertentu peranan tersebut harus dipilah-pilah antara yang satu dengan yang lain, dasar pemilihan merupakan soal pengaruh, pemimpin mempengaruhi dan orang lain dipengaruhi" (www.ikachaibrahim.com).

Menurut Susilo Martoyo (1994) mengatakan bahwa kepemimpinan mengandung tiga hal pokok yaitu: "Pertama: adanya seorang pemimpin yang memiliki wibawa, posisi, kemampuan dan legitimasi. Kedua: adanya bawahan pengikut yang memiliki derajat berbeda dalam kemampuan, motivasi, harapan dan kebutuhan. Ketiga: adanya situasi dan kondisi yang berbeda dari setiap tugas."

Kepemimpinan adalah kemampuan seseorang mempengaruhi dan memotivasi orang lain untuk melakukan sesuatu sesuai tujuan bersama. Kepemimpinan meliputi proses mempengaruhi dalam menentukan tujuan organisasi, memotivasi perilaku pengikut untuk mencapai tujuan, mempengaruhi untuk memperbaiki kelompok dan budayanya. Oleh sebab itu terkait dengan kepemimpinan ini disebutkan bahwa "Great Leader with Great Team for Great Results." 
Kepemimpinan adalah seni untuk mempengaruhi dan menggerakkan orang-orang sedemikian rupa untuk memperoleh kepatuhan, kepercayaan, respek, dan kerjasama secara loyal untuk menyelesaikan tugas. Fungsi pemimpin dalam suatu organisasi tidak dapat dibantah merupakan sesuatu fungsi yang sangat penting bagi keberadaan dan kemajuan organisasi yang bersangkutan. Pasa dasarnya fungsi kepemimpinan memiliki dua aspek yaitu pertama adalah Fungsi Administrasi, yakni mengadakan formulasi kebijaksanaan administrasi dan menyediakan fasilitasnya dan yang kedua Fungsi sebagai Top Manajemen, yakni mengadakan planning, organizing, staffing, directing, commanding, controlling, stetelah itu terwujud hendaknya mampu juga untuk melaksanakan suatu bentuk analisis fungsi manajemen yakni SWOT terdiri dari : kekuatan (strengths), kelemahan (weaknesses), peluang (opportunities), dan ancaman (threats). Yang perlu diperhatikan adalah bahwa untuk dapat mengembangkan gaya kepemimpinan situasional atau Situational Leadership and Leading Dynamic Team, seseorang perlu memiliki tiga kemampuan khusus yakni : (1) Creative Thinking and Problem Analysis, kemampuan analisis (analytical skiils) yakni kemampuan utnuk menilai tingkat pengalaman dan motivasi bawahan untuk menyelsaikan problem dengan analisis dalam melaksanakan tugas, (2) Kemampuan untuk fleksibel (flexibility atau adaptability skills) yaitu kemampuan untuk menerapkan gaya kepemimpinan yang paling tepat berdasarkan analisa terhadap situasi dan (3) Communication in Team dan Across Team, kemampuan berkomunikasi (communication skills) di dalam Tim maupun lintas tim, kemampuan untuk menjelaskan kepada bawahan tentang perubahan gaya kepemimpinan yang kita terapkan dan menjalin hubungan baik dengan tim lain. Ketiga kemampuan di atas sangat dibutuhkan bagi seorang pemimpin, sebab seorang pemimpin harus dapat melaksanakan tiga peran utamanya yakni peran interpersonal, peran pengolah informasi (information processing), serta peran pengambilan keputusan (decision making).

\section{PEMBAHASAN}

Beberapa tahun yang lalu, jurnalis senior Thomas L. Friedman menulis buku Lexus and the Olive Tree. Ia mengatakan, dunia baru yang ditandai oleh globalisasi selalu ditandai oleh pertarungan dua 
kepentingan, yaitu antara mereka yang mengejar kekayaan (the Lexus) dan mereka yang masih bertempur mempertahankan identitas lama (pohon zaitun, the Olive). Friedman melukiskan globalisasi dari pengalamannya menikmati sushi di atas kereta api secepat peluru di Jepan, sementara bacaannya adalah konflik tiada akhir di Timur Tengah. Konflik yang mempertahankan old identity, seperti petani di Mesuji atau petambang di Bima dan para pemburu yang kehilangan lahan di Papua dan Kalimantan.

'Globalization refers to global economic integration of many formerly national economies into one global economy, mainly by free trade and free capital mobility, but also by easy or uncontrolled migration. It is the effective erasure of national boundaries for economic purposes.'

'Globalization is the increasing integration of economies around the world, particularly through trade and financial flows. It also refers to the movement of people (labor) and knowledge (technology) across international borders. It refers to an extention beyond national borders of the same market forces that have operated for centuries at all levels of human economic activity.'

Globalisasi ekonomi adalah suatu proses historis, dan istilah tersebut baru digunakan secara populer sejak tahun 1980-an, sejak perkembangan teknologi yang sangat memudahkan dan mempercepat menyelesaikan transaksi internasional, baik dalam hal arus perdagangan maupun keuangan. Dengan runtuhnya sistem ekonomi sosialis, maka tinggal satu sistem ekonomi besar yang bertahan, yaitu kapitalis. Sistem kapitalis yang bersifat liberal bercirikan pasar bebas dan terbuka, serta perdaganan bebas. Inilah yang terus mendorong ke arah globalisasi. Liberalisasi ekonomi adalah tahap pertama globalisasi. Tidak dapat dipungkiri lagi bahwa globalisasi berpengaruh pada semua tingkah laku manusia dan berdampak dalam tingkat yang berbeda pada budaya, masyarakat dan manusia. Memang, intensifikasi hubungan global lebih mendekatkan manusia dan budaya, namun juga bahwa budaya lokal dipengaruhi oleh faktor-faktor eksternal, yang asing terhadap realitas yang sudah ada.

Globalisasi sering dilihat orang bukan hanya sebagai gejala atau proses baru, tetapi juga sebagai ideologi baru, bahkan juga sebagai budaya baru. Sebagai ideologi, globalisasi percaya pada faham, kebebasan penuh khususnya kebebasan ekonomi dan perdagangan, yang telah terbukti mampu mensejahterakan banyak negara. 
Tumbangnya konsep ekonomi sosialis menguatkan keyakinan ini. Globalisasi dan kebebasan adalah semacam lawan dari nasionalisme dan proteksionisme. Oleh banyak negara yang sedang berkembang, globalisasi sering dirasakan dan dianggap sebagai neoliberalisme atau neokapitalisme. Kalau diperhatikan, ada empat aspek globalisasi yaitu perdagangan, pergerakan modal, pergerakan orang, serta penyebaran ilmu pengetahuan dan teknologi.

\section{Perdagangan}

Negara-negara yang sedang berkembang memang telah mampu meningkatkan penyertaannya dalam perdagangan dunia, dari 19\% di tahun 1971 menjadi 295 di tahun 1999, namun tampak ketimpangan untuk beberapa regional. Misalnya negara-negara ekonomi industri baru di Asia memang mengalami kemajuan, sedangkan negara-negara Afrika secara keseluruhan tetap saja mengalami kemiskinan. Peningkatan adalah terutama pada perdagangan barang-barang hasil manufaktur. Perdagangan hasil industri primer yaitu pertanian, yang paling banyak diproduksi oleh negara-negara miskin, justru mengalami kemunduran.

\section{Pergerakan Modal}

Seperti yang banyak diasosiasikan orang dengan globalisasi yaitu pergerakan modal, maka memang selama tahun 1990-an terjadi kenaikan pergerakan besar-besaran modal swasta ke negara-negara yang sedang berkembang. Tetapi sejak tahun 1980-an bantuan resmi pemerintah untuk negara-negara sedang berkembang mengalami pengurangan. Mengalirnya modal swasta tersebut terutama dalam bentuk investasi modal asing secara langsung.

\section{Pergerakan Orang}

Pekerja berpindah dari satu negara ke negara lain dalam rangka mencari penghidupan yang lebih baik. Pergerakan pekerja ini paling banyak antar negara yang sedang berkembang, tetapi juga dari negara yang sedang berkembang ke negara yang sudah maju. Globalisasi 
memudahkan brain drain tenaga dari negara yang sedang berkembang ke negara-negara maju, disamping juga memudahkan perpindahan pekerja dari negara maju ke negara berkembang.

\section{Penyebaran Ilmu Pengetahuan Dan Teknologi}

Pertukaran informasi adalah aspek yang tidak dapat dilepaskan dari globalisasi, yang sering kali dilupakan. Misalnya investasi asing secara langsung tidak hanya membawa modal fisik, tetapi juga membawa teknologi dan keterampilan. Teknologi dan keterampilan baru ini merupakan cara dan alat yang murah bagi pengenalan dan penguasaan teknologi bagi negara-negara yang sedang berkembang.

\section{Globalisasi Dan Internasionalisasi}

Istilah globalisasi sering kali dikacaukan dengan istilah internasionalisasi, sedangkan sebetulnya keduanya mempunyai arti yang sangat berbeda. Oleh karena itu perlu adanya penjelasan seperlunya mengenai dua konsep yang kelihatannya hampir sama, tetapi sangat berbeda tersebut.

\section{Internasionalisasi}

Internasionalisasi adalah makin berkembangnya kerja sama internasional dalam bidang ekonomi, perdagangan, pendidikan, politik, budaya dan sebagainya. Inter-nasional berarti antar negara dan di antara negara. Unit basis masih ekonomi nasional, identitas dan budaya masih budaya nasional masing-masing. Internasionalisasi adalah kegiatan atas dasar kesadaran masing-masing, atas dasar suka rela, atas dasar pilihan tertentu, bukan suatu tindakan yang terpaksa. Dalam perdagangan internasional, kompetisi berdasarkan keunggulan kompetitif, dan tata cara dapat diatur atas kesepakatan pihak-pihak yang terkait.

Dalam teori klasik Adam Smith dan Ricardo masyarakat nasional menerima baik pekerja nasional maupun kapital nasional dan dua kelas ini bekerja sama, meskipun kadang-kadang dengan konflik, untuk menghasilkan produk nasional dari sumber daya nasional. Produk nasional ini bersaing dalam pasar internasional dengan produk negara 
lain, yang dihasilkan dengan kapital, pekerja, dan sumber daya negara masing-masing. Ini adalah internasionalisasi dalam perdagangan. Dalam internasionalisasi, masing-masing negara masih sepenuhnya berdaulat dan mengatur persyaratan perdagangan sedemikian rupa sehingga kepentingan rakyat negara dapat tetap diperhatikan.

Dalam perguruan tinggi, internasionalisasi dapat berupa pertukaran dosen dan mahasiswa, pengadaan program penelitian bersama, bantuan program studi lanjut bagi pada dosen, pengadaan program ijasah ganda (dual degree programme), program kuliah bersama, dan sebagainya. Setiap Perguruan Tinggi bebas untuk memilih universitas mitra di luar negeri, memilih jenis program kerjasama, memilih waktu dan durasi kerja sama.

\section{Pro Dan Kontra Globalisasi}

Dari penjelasan di atas, sudah terdapat hal-hal baik dan hal-hal yang kurang baik mengenai globalisasi dipandang dari berbagai sudut kepentingan. Pandangan dan debat antara yang pro dan yang kontra globalisasi masih terus berlangsung dengan argumentasi masingmasing. Untuk memahami beberapa pandangan dari mereka, ada baiknya pendapat dari dua kubu tersebut dikutip dan dicatat sebagai berikut.

\section{a. Pandangan Yang Pro Globalisasi}

Mungkin pandangan dari kubu ini dapat diwakili oleh Thomas Friedman yang menulis buku best-selling berjudul The Lexus and the Olive Tree (LOT). Thomas Friedman adalah seorang kolumnis mengenai peristiwa internasional dari New York Time, yang karena bukunya tersebut, sering kali dikira sebagai yang berwenang membicarakan mengenai globalisasi. Thomas Friedman dikenal sebagai salah satu orang yang getol mengkritik gerakan sosial baru yang anti globalisasi. Thomas Friedman, sampai April 2002, telah memenangkan tiga Pulitzer Prize. Beberapa pokok pandangan dari Thomas Friedman yang dimuat dalam LOT tersebut, antara lain menyebutkan bahwa:

Kebenaran fundamental mengenai globalisasi adalah bahwa globalisasi itu timbul dari bawah, dari tingkat jalanan, dari dasar jiwa

setiap orang, dan dari aspirasi terdalam mereka. Globalisasi adalah 
produk dari demokratisasi di bidang keuangan, teknologi, dan informasi, tetapi yang mendorong ketiganya adalah keinginan dasar setiap manusia yaitu kehidupan yang lebih baik, kehidupan dengan pilihan lebih banyak mengenai apa yang dimakan, apa yang dipakai, dimana bertempat tinggal, kemana bepergian, bagaimana bekerja, apa yang dibaca, apa yang ditulis, dan apa yang dipelajari.

Globalisasi meningkatkan perkembangan ekonomi dan neoliberalisme adalah satu-satunya bentuk globalisasi, yang justru menguntungkan negara-negara miskin. Pengembangan teknologi informasi dan peralatan serta praktek kapitalis global bersifat egaliter dan demokratis. Orang dapat berbicara mengenai alternatif terhadap pasar bebas dan integrasi global dan mereka dapat menuntut alternatif, mereka bahkan bersikukuh pada jalan ketiga, tetapi sampai sekarang, jalan lain itu tidak ada.

Thomas Friedman malah menyebutkan bahwa: Globalization is not just some economic fad, and it is not just passing trend. It is an international system, the dominant international system that replaced the Cold War system.

Beberapa slogan yang dicanangkan oleh kelompok yang pro globalisasi ini antara lain adalah: Aliran investasi global lebih tinggi dari selama ini. Globalisasi memegang kunci untuk mengakhiri kemiskinan dunia. Perdagangan bebas membantu negara sedang berkembang untuk menyusul. Pertumbuhan itu baik untuk yang miskin. Pemrotes perdagangan bebas 'memerangi musuh yang salah alamat'. Multinasional adalah kekuatan yang positif. Globalisasi menawarkan jalan keluar dari kemiskinan. Perdagangan dunia adalah tenaga pendorong pertumbuhan.

\section{b. Pandangan Yang Anti Globalisasi}

Sebaliknya para pendukung anti globalisasi menganggap bahwa para pendukung globalisasi umumnya menghindari analisis kuantitatif yang seimbang dan komprehensif mengenai kemajuan ekonomi dan kesejahteraan manusia di negara-negara yang sedang berkembang sejak berkembangnya globalisasi. Tindakan menghindar tersebut jelas kelihatan, karena pemaparan angka-angka statistik perkembangan ekonomi dan indikator kesejahteraan penduduk sejak tahun 1980 di negara-negara yang belum atau sedang berkembang akan 
menggagalkan argumentasi mereka sendiri. Globalisasi memang meningkatkan akses perdagangan dari negara-negara maju ke pasar negara-negara yang sedang berkembang, tetapi tidak berlaku sebaliknya, karena negara yang sedang berkembang belum cukup siap dalam permodalan, teknologi produksi, pemasaran dan sebagainya. Jadi, negara kaya bertambah kaya dan negara miskin bertambah miskin. Khusus mengenai LOT dari Thomas Friedman, beberapa kritik telah disampaikan, antara lain ialah:

Referensi yang digunakan Thomas Friedman bukanlah literatur ilmiah yang bergengsi di bidang ekonomi dan perdagangan, tetapi majalah seperti The Economist yang notabene dimiliki oleh korporasi raksasa. Argumentasi Thomas Friedman tidak disertai dengan catatan kaki, grafik, dan statistik, tetapi semata-mata oleh argumentasi kualitatif yang tidak meyakinkan. Argumentasi Thomas Friedman sangat berat sebelah dan bukunya hanya sekedar semacam who's who mengenai kapitalisme global. Sifat egaliter dan demokratis dari kapitalisme global hanyalah merupakan fantasi Thomas Friedman belaka karena statistik tidak mendukung pendapat itu.

Sesuai dengan data Federal Reserve, pada tahun 1998, 10\% orang terkaya Amerika memiliki lebih dari $82 \%$ stock, $86 \%$ bond, dan $91 \%$ dari aset bisnis. Untuk daerah-daerah tertentu, kurang dari $0,5 \%$ orang terkaya memiliki lebih dari $31 \%$ stock, hampir $32 \%$ bond, dan hampir $55 \%$ dari aset bisnis. Angka ini lebih buruk dibandingkan dengan data tahun 1990, dimana perbandingan masih $60: 1$ dan $30: 1$ pada tahun 1960. Pemujaan Thomas Friedman terhadap kebebasan dan demokrasi secara implisit disangkal sendiri dengan mengatakan bahwa: Argumentasi Thomas Friedman untuk mengkritik penentangnya sangatlah dangkal seperti berikut ini: 1) neoliberalisme adalah satusatunya bentuk globalisasi, 2) globalisasi mendorong pertumbuhan ekonomi, 3) pertumbuhan ekonomi dan tetesan-kebawah adalah satusatunya cara yang membantu negara yang miskin, 4) oleh karena itu, neoliberalisme adalah teman terbaik yang dimiliki negara-negara miskin dan siapa yang menentang neoliberalisme, berarti menyetujui kemiskinan global.

Para pendukung anti globalisasi atau sebetulnya lebih tepat dinamakan anti pengaruh buruk globalisasi adalah para aktivis, lembaga swadaya masyarakat, dan elemen lain yang merupakan gerakan masyarakat sipil yang tumbuh dan berkembang. Gerakangerakan ini secara aktif melancarkan usulan-usulan yang penting untuk 
meningkatkan dan menjaga dunia yang lebih lestari, egaliter, dan demokratis.

\section{Dorongan Perubahan Dari Luar}

Dorongan perubahan dari luar adalah kekuatan demokrasi yang menjadi pondasi dari globalisasi itu sendiri. globalisasi harus didorong pula oleh terjadinya perubahan dari luar, yaitu:

\section{a. Transparansi}

Transparansi adalah segala sesuatu yang menyebabkan segala kebaikan itu menjadi nampak. Menurut Richard Medley, seorang analis resiko politik mengatakan bahwa transparansi adalah apa yang memungkinkan berkembangnya optimisme dan ketidaktakutan akibat kebebasan yang muncul.

\section{b. Standardisasi}

Semakin banyak kawanan menanamkan modalnya di pabrik atau pasar di negara yang berbeda, semakin banyak pula negara yang ingin mendapatkan investasi dari kawanan dan semakin banyak negara yang ingin masuk dalam daftar bursa salah satu pasar utama, semakin banyak tekanan untuk mematuhi standar pelaporan keuangan internasional.

\section{c. Korupsi}

Sistem globalisasi dapat mempengaruhi korupsi dengan cara positif (baca cerita tentang kudeta militer yang terjadi di Pakistan, 12 Oktober 1999). Dorongan perubahan dari luar menimbulkan biaya yang tinggi untuk beberapa negara yang mentolerir korupsi.

\section{d. Kebebasan Pers}

Contohnya Cina. Cina akan memiliki pers bebas. Perubahan dari luar akan mendorongnya. Cina sebenarnya tidak memiliki pers yang bebas, bertanggung jawab, dan tidak korup dalam keuangan sehingga dapat menyoroti secara kredibel saham berkualitas dan mengekspos 
secara kejam perusahaan Cina yang tidak melaporkan data keuangannya tepat waktu, akurat, dan transparan.

\section{e. Pasar Obligasi Dan Saham}

Kawanan elektronik telah lama mendorong terciptanya pasar obligasi, selain untuk memenuhi hasratnya sendiri, juga dengan teraturnya pasar saham dan obligasi akan mendorong demokratisasi dan transparansi keuangan yang lebih besar.

\section{f. Demokratisasi}

Kawanan elektronik akan meningkatkan tekanannya terhadap demokratisasi umumnya untuk tiga alasan yang sangat penting; fleksibel, legitimasi, dan kontinuitas. Artinya bahwa semakin cepat dan semakin besar pengaruh kawanan, serta semakin lancar dan terbuka perekonomian global, semakin fleksibel Anda perluk untuk keluar dari kawanan dan melindungi diri sendiri dari padanya.

Sementara orang-orang selalu dapat menemukan kekecualian, saya percaya sebagai aturan umum, semakin demokratis, bertanggung jawab, dan terbuka sebuah pemerintahan, semakin berkurang kemungkinannya sistem keuangannya diserang. Ketika sistem keuangan diserang dan diguncang, lebih cepat sistem itu menyesuaikan diri untuk mengubah keadaan. Juga semakin terbuka dan semakin demokratisnya masyarakat, dan semakin banyaknya masukan yang didapatkan, semakin baik kesempatan yang dimiliki untuk melakukan perbaikan dipertengahan jalan sebelum melintasi jurang, dan semakin mudah membawa manajer baru dan mengeluarkan yang tidak layak.

\section{Kepemimpinan Dalam Keberagaman Indonesia}

Pemimpin ideal di negara multikultur macam Indonesia adalah yang berjiwa kenegarawan, yang berani tidak popular, dan tak terkooptasi suara mayoritas, demi kenyataan pluralism. Semboyan itu sangatlah tepat karena pada kenyataannya bangsa Indonesia memanglah berciri demikian. Bumi Indonesia ini dihuni oleh beragam suku yang berbeda-beda agama, bahasa, budaya, dan rasnya. Para

pendiri NKRI memberi ciri bangsa Indonesia yang demikian itu dengan 
sebutan "Bhineka Tunggal Ika," yaitu berbeda-beda tetapi tetap satu. Beragam suku yang berbeda dalam hal agama, bahasa, budaya, dan ras itu hidup bersatu sebagai warga Negara Kesatuan Republik Indonesia (NKRI).

Bangsa Indonesia juga memiliki kekayaan alam yang melimpah, yaitu kekayaan tumbuhan, hewan, tambang, dan laut. Sumber daya manusia yang kuat ini akan mampu mengelola dan mengolah sumber daya alam untuk menciptakan kehidupan bangsa Indonesia yang adil dan makmur. Selain berciri Bhineka Tunggal Ika, bangsa Indonesia juga dikenal sebagai bangsa yang kaya akan sumber daya manusia dan sumber daya alam. Sampai saat ini penduduk Indonesia berjumlah sekitar dua ratus lima pulu juta orang.

Pemimpin yang dibutuhkan oleh bangsa Indonesia adalah pemimpin yang berjiwa Pancasila. Pancasila yang menjadi dasar bangunan kesatuan dan persatuan bangsa Indonesia yang beragam itu. Pemimpin yang berjiwa Pancasila adalah pemimpin yang menghayati dan mengamalkan nilai-nilai yang terkandung dalam lima sila dari Pancasila dalam hidup bermasyarakat, berbangsa, dan bernegara. Berjiwa Pancasila ini merupakan karakteristik yang pertama dan utama bagi pemimpin bangsa Indonesia. Karakteristik yang lain merupakan penjabaran atau penonjolan salah satu karakter dari berjiwa Pancasila. Untuk mengelola sumber daya manusia dan sumber daya alam dalam rangka meraih kehidupan yang adil dan makmur itu, dibutuhkan karakteristik pemimpin yang sesuai dengan ciri khas bangsa Indonesia.

Pemimpin yang dibutuhkan oleh bangsa Indonesia adalah pemimpin yang menghargai keberagaman karena ciri utama bangsa Indonesia adalah beragam. Pemimpin semua golongan adalah pemimpin yang bersikap adil, pemersatu, dan tidak diskriminatif. Pemimpin yang menghargai keberagaman adalah pemimpin yang mampu menciptakan kesatuan dalam keberagaman. Pemimpin yang demikian adalah pemimpin bagi semua golongan. Dewasa ini, kejujuran dan integritas merupakan karakter yang hakiki dimiliki oleh para pemimpin di Indonesia. Bangsa Indonesia membutuhkan pemimpin yang jujur dan dapat dipercaya, yaitu tidak menipu, tidak membohongi, dan tidak korupsi. Karakteristik pemimpin yang dibutuhkan bangsa Indonesia adalah pemimpin yang jujur dan terpercaya.

Pemimpin harus menunjukkan komitmennya kepada orang-orang yang dipimpinnya untuk meraih impian masa depan yang lebih baik. 
Dewasa ini, bangsa Indonesia membutuhkan pemimpin yang visioner. Pemimpin yang berkarakter demikian memberikan harapan dan membangkitkan semangat untuk mewujudkan harapan-harapannya. Pemimpin yang visioner adalah pemimpin yang bersikap positif dan penuh semangat dalam memperjuangkan masa depan yang lebih baik.

Pemimpin yang kompeten adalah pemimpin yang mampu menunjukkan keahliannya dalam memimpin. Pemimpin yang dibutuhkan oleh bangsa Indonesia adalah pemimpin yang kompeten. Pemimpin yang demikian adalah pemimpin yang demokratis, tidak otoriter, mau karakteristik pemimpin yang dibutuhkan bangsa Indonesia, yaitu berjiwa Pancasila, menghargai keberagaman, jujur dan terpercaya, visioner, kompeten, mendengarkan aspirasi yang dipimpinnya, peduli, dan mampu mencegah atau menyelesaikan konflik.

Ironisnya, masih banyak yang tidak mengindahkan hal tersebut. Ada upaya mengeliminasi kebhinekaan dan upaya menyodorkan keseragaman dengan segala cara. Termasuk melakukan tindakan anarkis dan kekerasan yang justru menimbulkan masalah baru di masyarakat. Banyak contoh yang bisa disebutkan. Peristiwa yang belakangan marak adalah aksi-aksi terorisme yang mengatasnamakan agama. Bahkan, banyak korban terorisme yang ternyata memiliki agama dan keyakinan yang sama dengan pelaku teror. Hal ini menunjukkan bahwa kelompok teroris benar-benar musuh bersama yang harus diberantas. Jika tidak, maka akan terus merongrong perdamaian negeri ini. Terlebih lagi, muncul kelompok-kelompok teroris yang memiliki jaringan di tingkat internasional. Contohnya ISIS yang memiliki simpatisan di negara-negara lain (termasuk Indonesia). Beberapa kasus terorisme di Indonesia pun dilakukan oleh mereka yang telah menyatakan setia kepada ISIS.

\section{KESIMPULAN}

Analogi the Lexus yang menggambarkan kekayaan dan mereka yang masih bertempu mempertahankan identitas lama (pohon zaitun, the Olive), adalah sebuah realita dalam praktek kepemimpinan Indonesia, ada kecenderungan menguasai dari satu pihak. Hal ini sangat bertolak belakang dengan jiwa luhur Indonesia dalam keberagaman. Kepemimpinan seorang pamong akan dapat mengelola diri, kelompok, 
dan lingkungan dengan baik. Khususnya dalam penanggulangan masalah yang relatif pelik dan sulit. Disinilah dituntut kearifkan seorang pemimpin dalam mengambil keputusan agar masalah dapat terselesaikan dengan baik.

Pemimpin yang dibutuhkan oleh bangsa Indonesia adalah pemimpin yang berjiwa Pancasila. Pancasila yang menjadi dasar bangunan kesatuan dan persatuan bangsa Indonesia yang beragam itu. Pemimpin yang berjiwa Pancasila adalah pemimpin yang menghayati dan mengamalkan nilai-nilai yang terkandung dalam lima sila dari Pancasila dalah hidup bermasyarakat, berbangsa, dan bernegara. Berjiwa Pancasila ini merupakan karakteristik yang pertama dan utam bagi pemimpin bangsa Indonesia. Karakteristik yang lain merupakan penjabaran atau penonjolan salah satu karakter dari berjiwa Pancasila. Untuk mengelola sumber daya manusia dan sumber daya alam dalam rangka meraih kehidupan yang adil dan makmur itu, dibutuhkan karakteristik pemimpin yang sesuai dengan ciri khas bangsa Indonesia.

Seorang pemimpin boleh berprestasi tinggi untuk dirinya sendiri, tetap itu tidak memadai apabila ia tidak berhasil menumbuhkan dan mengembangkan segala yang terbaik dalam diri para bawahannya. Kesimpulan bahwa: Pemimpin adalah orang yang mendapat amanah serta memiliki sifat, sikap, dan gaya yang baik untuk mengurus atau mengatur orang lain. Berdasar kepada azas Pancasila, seorang pamong yang juga sebagai pemimpin harus bersikap sebagai pengasuh yang mendorong, menuntun, dan membimbing asuhannya, Ing Ngarsa Sung Tuladha: pamong yang berperan sebagai pemimpin harus mampu dengan sifat dan perbuatannya menjadikan dirinya pola anutan dan ikutan bagi orang-orang yang dipimpinnya; Ing Madya Mangun Karsa: pamong harus mampu membangkitkan semangat berswakarsa dan berkreasi pada orang-orang yang dibimbingnya; dan Tut Wuri Handayani: pamong harus mampu mendorong orang-orang yang diasuhnya berani berjalan di depan dan sanggup bertanggung jawab. 


\section{DAFTAR PUSTAKA}

Fahri Karakas, (2010). "Spirituality and Performance in Organization: a Literature Review." Journal of Business Ethics, 94(1).

Guilory dikutip Katinka Nicou, Extracts from "Spirituality in the Workplace," What Are They Implications for Modern Organizations Associety Embraces New Concepts of Spiritualisem, 2002, h. 1-17, diakses tgl 20 Feb 2013

http://www.integrateod.com/pdfs/022607 Spirituality in the Workplace.pdf

Harold A. Mitroff, Elizabeth A. Denton, Spirituality in the Workplace, http://www.freebizplan.org/business strategies/soft skills/spirituality. htm (diakses tgl. 20 Februari 2013),

Judith A. Neal, "Leadership and Spirituality in the Workplace", Executive Director, Association For Spirit at Work, www.spiritatwork.org (C2005 by Judith Neal, used by permission of the author.

Mitroff dan Deton dikutip Oliveira A. "The Place of Siprituality in Organizational Theory," EJBO Electronic Journal of Business Ethics and Organization Studies, Vol. 9, No. 2, http://ejbo.jyu.fi/pdf/ejbo vol9 no2 pages 17-21.pdf (diakses tgl 4 Maret 2013).

Robbins. Stephen, Timothy A. Judge, Organizational Behaviour, $15^{\text {th }}$ Edition New Jersey: Prentice Hall, 2013.

Smith and Rayment dalam Tevichapong Passagorn, "Individual Spirit at Work and Its Relationship"

\section{INTERNET :}

https://jalandamai.org/indonesia-jenjam-dalam-keberagaman.html https://syaharuddin.wordpress.com/2010/04/10/masalah-keragamandalam-masyarakat-indonesia/ http://www.academia.edu/7341471/A-

Keberagaman_dalam_masyarakat_Indonesia 